\title{
Resource Utilization and Livelihood Assets Ownership by Nomadic Pastoralists in Nasarawa State, Nigeria
}

\author{
A. A. Girei \\ Department of Agricultural \\ Economics and Extension, \\ Nasarawa State University, \\ Keffi, Nigeria.
}

\author{
J. G. Akpoko \\ Department of Agricultural \\ Economics and Rural \\ Sociology, Ahmadu Bello \\ University, Zaria, Kaduna \\ State, Nigeria.
}

\author{
S. B. Ohen \\ Department of Agricultural \\ Economics, University of \\ Calabar, Calabar, Cross River \\ State, Nigeria.
}

\begin{abstract}
The study analyzed resource utilization and livelihood assets of nomadic pastoralists in Nasarawa State, Nigeria. A survey design method was adopted for the study. A reconnaissance survey was conducted in the Area to identify the major water points where pastoralists are found. In each Local District, one water point was randomly selected. Estimate from the reconnaissance survey revealed the average number of nomadic pastoralists, out of which $30 \%$ were selected for the study. The primary data were collected with the aid of structured questionnaire. Descriptive Statistics was used to achieve research objectives. The study revealed that the mean number of cattle, sheep and goats owned by the respondents were $168.60,57.86$ and 31.28 , respectively, while all the respondents used natural pasture as feeds. Land tenure was the highest ranked constraint to majority $(64.4 \%)$ of the nomadic pastoralists in the study area. Based on the findings, the study recommended that rangeland should be made available by government and accessible to nomadic pastoralists and a broader research should be conducted on resource utilization and livelihood assets of nomadic pastoralists in Nasarawa State.
\end{abstract}

\section{Keywords}

Resource utilization, livelihood assets, Nomadic pastoralists, Nigeria

\section{INTRODUCTION}

Nomadic is a situation whereby people move with their animals from place to place, while pastoralism is defined as a situation whereby people herd animals to sustain their livelihoods (Bhasin, 2011). Despite various criticisms about nomadic pastoralism and its relevance in modern world, it remains a successful strategy to support a population where there is little access to social, cultural, physical, biological and environmental amenities (Bhasin, 2011). Thus, pastoralists are people whose major source of livelihoods is livestock herding, and the importance of this profession particularly its contribution to food production in the developing world cannot be over emphasized. This has made pastoralism to become a vehicle of guaranteeing food security in marginalized rural communities.

Pastoralists usually live in areas that are rural and remote so as to be able to access pastures for their animals and possibly to avoid conflict with crop farmers. This has resulted in marginalization as no one seems to remember and care for them in any social and economic consideration despites multiplicity of taxes levied on them by various authorities. It is worth mentioning that through pastoralism, production of milk, cheese, yoghurt, hide, and beef are enhanced which serve as raw materials for a number of industries in the urban areas. Pastoralists also use their animals as beast of burden to work on their farms (e.g. camels, donkeys and cattle) and to a large extent, animal wastes are a good source of organic manure for crop production in the local communities (Carl, 2014). Despite all these, pastoralists live in extreme poverty or below the marginalized threshold (IFAD, 2001). This is due to the fact that the contribution of these income generating activities is minimal. They also have modern low access to technologies to improve output, lack of access to inputs such as credit and market facilities in the rural areas (Leeuwis and Pyburn, 2002). Carter \& Barett (2007) stated that people who are below the marginalized threshold are ruined as they cannot access social facilities due to poverty; on the contrary, people above the threshold are productive and advanced.

In Nigeria, 90 per cent of cattle are owned by the Fulani ethnic group and they constitute the core of traditional nomadic pastoralists. These groups of people in the past were commonly settled in the arid and semi-arid regions of the country. However, due to their migrating nature, they are now found in every part of the country in search of grazing land and water for their animals (Umar, 2006).

Pastoralism in Nigeria context has marginalization as a defining characteristic. This is apparent because pastoralists do not play any role in decision making in the society and as such lack nearly all forms of economic and social benefits of life. In some occasions they are seen as strangers and sometimes regarded as illegal settlers (Umar, 2006). Pastoralists may be described as nomadic. Semi-settled (transhumant) or settled (sedentary agro-pastoralists) according to the degree of mobility. The semi-settled pastoralists are at times called transhumant agro pastoralists if they also practice cropping (Bates, 2014). As the livelihoods of pastoralists and sedentary agro-pastoralists depend on key resources such as land, water, forests, wildlife, livestock and pasture, these resources poses some challenges to their survival. In particular, these resources are diminishing from year to year, intensifying competition over their availability and causing violent conflict between pastoralists and other users. Against the foregoing background, the study seeks to answer the following research questions in Nasarawa State:

i. What are the resource utilization and livelihood assets of pastoralists?

ii. What are the breeds of livestock reared by the pastoralists?

iii. What are the livelihood constraints of the pastoralists? 


\subsection{Objectives of the Study}

The broad objective is to analyze the livelihoods of the pastoralists in the study area.

The specific objectives of the study are to: i) examine the resource utilization and livelihood assets, ii) identify the breeds of livestock reared by the pastoralist in the study, and iii) identify livelihood constraints of pastoralists in the study area.

\subsection{Justification of the Study}

This study explored the issues of resource utilization and livelihood assets of nomadic pastoralists in the study area. It is conceived against the view that security of livelihoods of nomadic pastoralists is important for sustainability of the nation's livestock sub-sector that contributes significantly to the nation's food security and health. The study, therefore, provides information on the livelihood security priorities of the nomadic pastoralists which could be used for policy formulation to address issues of sustainable livestock production in Nigeria.

Recent literature has emphasized the effects of the environment on peoples' livelihood strategies and the impact of resource use on the environment. The time to be apprehensive about how the limited natural resources in our environment are managed has come. Management of natural resources is a key factor in livestock production, consequently, attention must be given to their management. Resolving the conflict between crop farmers and cattle rearing competing for the limited natural resources is an enormous challenge. An understanding of factors that affects efficient and effective management of the natural resources to resolve this conflict is critical. This study provides that understanding.

The study would also provide sufficient sensitization among policy makers and as a veritable tool for development agencies for introducing innovative strategies for effective livestock production in Nasarawa State and Nigeria at large.

In addition, the results will serve as a building block for further studies.

\subsection{Livelihood Capital Assets of the Pastoral Household}

According to Nyangile (2013), assets are often represented as a pentagon in the sustainable livelihood framework, consisting of the following five categories: natural resources (also called natural capital), physical productive goods (physical capital), monetary resources (financial capital), manpower with different skills (human capital) and social networks of various kinds (social capital). The human capital includes labour, power, health and nutritional status, skills and knowledge. Natural capital is access to land, water, wildlife, flora and forest while social capital refers to those stocks of social trust, norms and networks that people can draw upon to solve common problems. It is mediated through kin, networks and group membership.

Examples of physical capital are ownership of houses, vehicles, agricultural equipment, livestock, and bicycles whereas financial capital involves money savings, gold/jewelry, access to regular income, net access to credit and insurance. Increasingly, it is being recognized that in addition to these five categories, it is important to include analysis of political capital. This goes beyond social capital, in that, an individual's stock of political capital will determine his/her ability to influence policy and the processes of government. An understanding of political capital is important in determining the ability of households and individuals to claim rights to assistance after a disaster or shock (FAO and ILO, 2009).

According to Carney (1999), livelihoods are capabilities, assets (including both social and material assets) and activities required for a means of living. A livelihood is sustainable when it can cope with and recover from stresses and shocks and maintain or enhance its capabilities and assets both now and in the future while not undermining the natural resources base. Livelihoods security therefore entails assessing the capabilities of a livelihoods system in maintaining and enhancing its assets and activities. DFID's concept of livelihoods assets (Human, Physical, Social, Natural and Financial assets) (DFID, 1999) was used and the indicators of these was provided by Fabusoro (2006). Highlighted below are the livelihoods capital assets of the pastoral Households in Nigeria:

\subsubsection{Natural Assets}

The natural capital assets of the pastoralists comprise land, forest and grasslands, grazing reserves, natural water-points and rivers and the livestock. Land is an important natural asset required by pastoralists in securing their livelihoods. The importance of land as a livelihood asset relies on its need for agricultural food production, and for livestock grazing. Pastoralists migrate from one location to the other in search for pasture and grasslands. The decision to settle in a location is dependent on the availability and suitability of such land for their livelihoods.

In Nigeria, experience has shown that pastoralists do not have secured access to land for farming and grazing. Where they have access, the tenure is usually limited and the size inadequate for livelihoods. The uncompromising need for land (farm lands, pasture, grassland, water points, etc) by pastoralists often results in incessant conflict between them and their host communities. The in-availability and or inadequacy of land also accounts for seasonal or permanent movement of pastoralists within and across regions in Nigeria (Fabusoro et al., 2007).

\subsubsection{Social Assets}

Social asset comprises social resources such as networks, membership of groups, relationships of trust and access to wider institutions of society upon which people draw in pursuit of livelihoods. It also includes social status and social privileges accruing from social networks. Social capital is traditionally strong and important among pastoralists, in that it minimizes risk, enables common resource management and provides safety nets in times of crisis (Nori et al., 2005). Pastoralists are known to be highly social people, contrary to general beliefs. They have highly effective social networks, among themselves. Pastoral groups are normally led by councils of elders who have the skills and wisdom to 'rule' their community and its resources. Without a reliable social networks and influence, the security of their livelihoods in southern Nigeria would be in doubt. Therefore, the pastoralists participate in local organizations, kinsmen groups and religious activities which designate social status and recognition to some of them thereby gaining some influence and voice at local levels (Fubusoro, 2007). The ability of the pastoralists to settle in a particular location is dependent of the information they could gather through networks and interaction.

Through social networking, pastoralists also participate in market activities of their host communities which increasingly represent a determining factor for their welfare in many 
regions. Market integration of pastoral economies varies substantially around the globe, and plays a relevant role in defining the vulnerability and the marginalization of herding communities. Generally, favorable terms of trade between pastoral and non-pastoral products are in fact vital for pastoralists' development, as the commoditization and sale of livestock products can ease the imbalance between variable pastoral production and household food needs.

\subsubsection{Human Assets}

Pastoralists' households are usually headed by the male gender, who take decisions on all matters relating to the household, especially those pertaining to primary livelihood, i.e;-cattle production. The women and girls in the pastoral household are usually involved in milk processing and marketing and water fetching, while the younger male in the household handle cattle grazing and caring. Usually, they do not work for pay but for milk and get one cattle after about two years of work. They are, however, expected to secure the herds and graze them regularly. Pastoralists often prefer to have their grown up sons as their herds' men (boys) so as to keep all the cattle within the same household.

The pastoralist human asset requires the skills, knowledge, ability to labor and good health which are important to the ability to pursue different livelihood strategies (Fabusoro, 2007). The pastoral human capital is characterized by an indepth knowledge of complex rangeland agro-ecological dynamics, critical in detecting resource availability to ensure livelihood strategies and coping mechanisms. Pastoralists' indigenous technical knowledge includes familiarity with patchy land resources and understanding erratic climatic patterns - both relevant in tracking environmental conditionstogether with an intimacy with livestock physiology and productivity (Nori, 2006).

\subsubsection{Physical Infrastructure Assets}

The physical infrastructure assets are vital to the livelihoods of pastoralists in ensuring the integration of remote settlements to other urban and sub-urban areas which provide for alternative and complementary resources such as health care, market exchanges, cereals, water, among others; especially during critical times (Nori et al., 2005). The basic infrastructure required by pastoralists includes transport, shelter, water, energy, communications and the production equipment and facilities. This enables them to pursue their livelihoods without major obstacles to movement and integration. However, pastoral settlements have limited access to and ownership of physical capital, especially compared to more settled communities, as a result of their constant mobility and of their economic and political marginalization.

\subsubsection{Financial Assets}

According to Nori et al. (2005), livestock represents the overwhelmingly most important form of financial capital for pastoralists, both in terms of stock and flows. It is the primary source of pastoral income, saving, loan, gift, investments and insurance. Threats to the herd or to the clan are therefore serious blows to pastoral financial capital. Variations in market prices and problems in accessing remittance income and market-based opportunities also represent major financial threats.

\subsection{Sources of Vulnerability in Pastoral Production System}

According to Bruijn and Dijk (1995) and Nori et al. (2005), the insecurities which pastoral societies have to face are many and they are part of the historical experience of the pastoralists. The resources which they control (livestock) and do not control (land, market, politics) have a large impact on their welfare choices and their interactions with the society at large. Vulnerability is a combination of exposure and risk and of the ability of households and individuals to cope with those risks and to recover from a shock or deterioration of current status (Chambers, 1989). The factors that make up vulnerability are important because they have direct impact on people's asset status and the options that are open to them in pursuit of beneficial livelihoods outcomes.

In general, pastoral vulnerability is shaped by ecological, economic and political forces at local, regional and global levels. The increasing encroachment of interests and pressures on grazing lands often results in processes that undermine the viability and sustainability of pastoral livelihoods, as they constrain their capacity to cope with the variability and the uncertainty of the bio-physical environment they depend upon. The transforming forces and processes of cultural, institutional and economic integration, when combined with emerging trends such as increasing population density, HIV/AIDS, urban expansion and environmental degradation, may trigger insecurity and conflict within pastoral communities. The resources which these groups control (livestock) and do not control (land, markets, politics) subsequently have a large impact on their welfare choices and their interactions with society at large-and the chances of such interactions turning violent (Fabusoro, 2006).

\subsection{Natural Grassland Resource}

Nigerian grassland grows on uncultivated land on which animals have access for grazing. They are found along roadsides and fallow lands in the coastal forest zones of Nigeria. Most of the natural grassland/rangeland assumes more important proportions in the open derived savannah zones of the country. Most farmers rely on natural grassland for their grazing animals. Carrying capacity of the natural grassland is very low compared to that of planted fertilized pastures. Productivity of natural grassland is affected by factors such as soil fertility, the amount of browse species available, density of canopy and management practices such as rotational grazing, stocking rate, fertilizer application, burning and the length of the resting period (Ademosun, 1974; Bamikole et al., 2004). Legumes are not generally common in natural grasslands therefore the contribution of fixed nitrogen is usually low to absent. Some of the commonest grasses in the natural grassland are Andropogon gayanus, Imperata cylindrica, Pennisetum pedicellatum and Hyparrhenia spp. They grow rapidly during the wet season, becoming fibrous and coarse and are under grazed because of the large amounts that become rapidly available. Their quality declines further during the dry season when they become standing hay and are subject to overgrazing (Omokaye et al., 2001). These grasses cannot meet the nutrient requirements of grazing livestock for most of the year. Even during the rains they can only satisfy maintenance requirements (Aregheore, 2001). Some of the browse species are Adenodolichos paniculatus, Desmodium velutinum and Sphenostylis schweinfurthii (Omokaye et al., 2001). During the dry season the most selected browse plants in natural grasslands by sheep and goats in sub humid Nigeria are Khaya senegalensis, Adenodolichos paniculatus and Gmelina arborea (Omokaye et al., 2001). Besides the savannah zones, natural grassland is found along road embankments and fallow lands in the tropical high forest zone. This is the grassland used by nomads who travel with their animals during the dry season to the south. In the high rainforest zone, grasses available in the 
natural grassland are Panicum maximum, Cynodonnlem fuensis, Pennisetum purpureum, some weeds and forbs (Aregheore, 2001). Also some trees such as Spondia smombinmay are found on fallows.

\section{METHODOLOGY}

\subsection{Study Area}

Nasarawa State has thirteen Local Government Areas (LGAs) and is divided into three agricultural zones namely: Central, Western and Southern. The study was conducted in the Southern Agricultural zone. Nasarawa State lies between latitudes $08^{\circ} 32^{\prime}$ and $8^{\circ} 18^{\prime}$ and longitudes $06^{\circ} 15^{\prime}$ and $08^{\circ} 50^{\prime}$. It occupies an area of about 27,117 square kilometers (Wikipedia, 2016). Nasarawa State is bounded in the north by Kaduna State, in the west by the Federal Capital Territory, in the south by Kogi and Benue States and the east by Taraba and Plateau States. The population of Nasarawa State is multi-ethnic and based on the 2006 census is about 1.86 million (NPC, 2006) and a projected population of $2,384,792$ million people applying a 2.8 percent growth rate for 2015.Agriculture is the dominant occupation of the inhabitants of Nasarawa State. The southern agricultural zone covers five LGAs namely: Awe, Doma, Keana, Lafia and Obi.

Nasarawa State is characterized by a tropical sub-humid climate with two distinct seasons. The wet season lasts from about the beginning of May and ends in October. The dry season is experienced between November and April. Annual rainfall figures range from $1100 \mathrm{~mm}$ to about $2000 \mathrm{~mm}$. The area falls within the southern guinea savanna zone. However, clearance of vegetation for farming, fuel wood extraction for domestic and cottage industrial uses and saw milling has led to the development of re-growth vegetation at various levels of serial development. Dense forests are few and far apart. Such forests are found in lowland areas, particularly where population pressure is less on the land. The major soil units of the area belong to the category of oxisols or tropical ferruginous soils (Nyagba, 1995). The major tribes are Alago, Eggon, Mada, Kanuri, Migili, and Gwandara. Others include Tiv, Hausa-Fulani, Igbo, Yoruba and Ninzo. Most of the people are farmers who engage in trading and artisan work as part time commercial activities. The average annual rainfall is approximately $107.3 \mathrm{~mm}$ and annual temperature range from $22.7^{\circ} \mathrm{C}-36.8^{\circ} \mathrm{C}$ (Meteorological department, NSG, 2008).

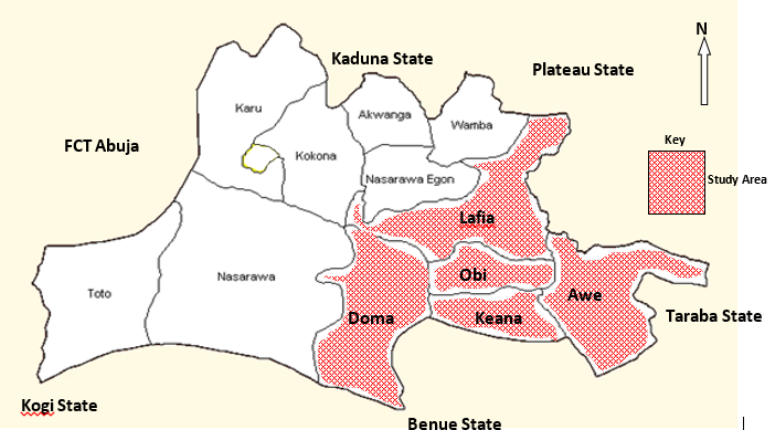

Figure 1: Map of Nasarawa State showing the study area

\subsection{Sampling Procedure}

Nomadic pastoralists are found where there is availability of water and feeds for their livestock. In the absence of accurate sampling frame for the nomadic pastoralists, a preliminary survey was conducted in the area to identify the major water points where pastoralists are found. Therefore, in each Local District, one water point was selected randomly. Estimate from reconnaissance survey revealed the average number of nomadic pastoralists, (provide the sample frame; i.e. population for each local district) out of which $30 \%$ (provide what this $30 \%$ represents in absolute value,) was targeted and included in the study to give a representative sample for the study.

\subsection{Data Collection}

Primary and secondary information were used for this study. The required primary data was collected by the use of questionnaire, whereas, the secondary information were sourced through journals, textbooks, internet, statistics, among others. (Explain in greater details how the questionnaire was administered; i.e.; who were the enumerators, what type of training did they receive in relation to this questionnaire administration, who were the field supervisors, who constituted your respondent, what month(s) was this activity conducted, etc). This is very vital for a study such as this to be scientific.

\subsection{Analytic Tools}

Descriptive statistics which involved the use of frequencies, percentages, and means were used. In addition, ranking was used to achieve objective vi. Several inferential statistical models were tried, but only descriptive statistics fit the nature of the data collected.

\section{RESULTS AND DISCUSSION}

\subsection{Resource Utilization and Livelihood Assets Ownership by the Respondents in the Study Area}

The distribution of respondents according to resources is presented in Table 1. The result shows that all, $90(100 \%)$ of the respondents utilize the natural grassland, $6(6.7 \%)$ utilize the pasture grassland while none of the respondents use rangeland. However, Table 1 presents the distribution of respondents according ownership of resources. It shows that majority $(91.1 \%)$ of the respondents own the cattle, about $4.4 \%$ of the cattle were owned by family while $4.4 \%$ were owned by self and others. Female play some major roles in processing and marketing of milk which serves as source of income especially, for basic needs of the family. On the ownership of sheep, it shows that most (83.3\%) of the sheep are owned by the respondents themselves, some proportion of the sheep, $9(10 \%)$ were owned by family whereas $6.7 \%$ were owned by self and others. Similarly, majority $(87.3 \%)$ of the respondents owned the goat kept themselves, family owned by $4.4 \%$ of the goats while $7.8 \%$ were owned by self and others. Table $4 \mathrm{~b}$ also shows that most $(83.3 \%)$ of the pasture grassland is owned by the respondents themselves while the remaining $16.7 \%$ of the pasture grassland was hired.

Merge Tables ( $1 \mathrm{a} \& \mathrm{~b})$ as one table.

Table 1: Distribution of respondents according to resources utilized in feeding their livestock

\begin{tabular}{lll}
\hline Resource & Frequency & Percentage \\
\hline Natural grassland & 90 & 100 \\
Pasture grassland & 6 & 6.7 \\
\hline
\end{tabular}

Source: Field survey, 2016 
Table 1: Distribution of respondents according to livelihood assets ownership

\begin{tabular}{|c|c|c|c|}
\hline Resource & Ownership & Frequency & Percentage \\
\hline \multirow{4}{*}{ Cattle } & Self & 82 & 91.1 \\
\hline & Family & 4 & 4.4 \\
\hline & Self and others & 4 & 4.4 \\
\hline & Total & 90 & 100 \\
\hline \multirow{4}{*}{ Sheep } & Self & 75 & 83.3 \\
\hline & Family & 9 & 10.0 \\
\hline & Self and others & 6 & 6.7 \\
\hline & Total & 90 & 100 \\
\hline \multirow{4}{*}{ Goat } & Self & 79 & 87.8 \\
\hline & Family & 4 & 4.4 \\
\hline & Self and others & 7 & 7.8 \\
\hline & Total & 90 & 100 \\
\hline \multirow{3}{*}{$\begin{array}{l}\text { Pasture } \\
\text { grassland }\end{array}$} & Owned & 5 & 83.3 \\
\hline & Hired & 1 & 16.7 \\
\hline & Total & 6 & 100 \\
\hline
\end{tabular}

Source: Field survey, 2016

\subsection{Breeds of Livestock Kept by the Respondents}

The distribution of respondents according the breeds of livestock kept is presented in Table 2. The result on the breeds of cattle kept shows that majority $(87.7 \%)$ kept Sokoto Gudali breed, $6.7 \%$ kept Rahaji, 3.3\% kept Bunaji while about 2.2\% kept Adamawa Gudali Breed. According to Lawal-Adebowale (2012), most of the breeds of livestock in Nigeria are indigenous breeds. Bourn et al. (2007) identified Bunji, Rahaji, Sokoto Gudali and Adamawa Gudali as the recognized cattle breeds in Northern Nigeria. However, the result on the breed of sheep kept by the respondent's shows that majority $(71.1 \%)$ of the respondents kept the Uda breed, $16.7 \%$ kept Yankasa, $6.7 \%$ of the nomadic pastoralists kept Balami while about 5.6\% kept the West African Dwarf breed. This agrees with the findings of Lawal-Adebowale (2012) who posited that, available breeds of sheep in Nigeria are the West African Dwarf, Balami, Uda and Yankasa. The result also shows that most $(85.6 \%)$ of the respondents kept the West African Dwarf goats while $14.4 \%$ of the nomadic pastoralist in the study area kept the Red Sokoto/Maradi breed. Similarly, Fabusoro et al. (2007) reported that the common breeds of goats found in the country include West African Dwarf (WAD), Sahel, African long-legged and Maradi.
Table 2: Distribution of respondents according to breeds of livestock kept

\begin{tabular}{|c|c|c|c|}
\hline $\begin{array}{l}\text { Type of } \\
\text { Livestock }\end{array}$ & Breed & Frequency & Percentage \\
\hline \multirow{6}{*}{ Cattle } & Bunaji & 3 & 3.3 \\
\hline & Rahaji & 6 & 6.7 \\
\hline & SokotoGudali & 79 & 87.7 \\
\hline & Adamawa & 2 & 2.2 \\
\hline & Gudali & 90 & 100 \\
\hline & Total & & \\
\hline \multirow{6}{*}{ Sheep } & West African & 5 & 5.6 \\
\hline & Dwarf & 6 & 6.7 \\
\hline & Balami & 64 & 71.1 \\
\hline & Uda & 15 & 16.7 \\
\hline & Yankasa & 90 & 100 \\
\hline & Total & & \\
\hline \multirow{5}{*}{ Goat } & West African & 77 & 85.6 \\
\hline & Dwarf & 13 & 14.4 \\
\hline & Sokoto & 90 & 100 \\
\hline & Red/Maradi & & \\
\hline & Total & & \\
\hline
\end{tabular}

\subsection{Livelihood Constraints of Nomadic Pastoralists in the Study Area}

Table 3 presents the distribution of nomadic pastoralists according to their livelihood constraints in the study area. The result indicated that land tenure is the most pressing constrain to majority $(64.4 \%)$ of the nomadic pastoralists in the study area and is ranked first. The result further showed that $23.3 \%$ of the respondents were faced with inadequate feed and nutrition, $11.1 \%$ were constrained by inadequate breeding programme, $12.2 \%$ considered pests and diseases infestation as a constraint to their livelihood, $8.9 \%$ indicated that inadequate capital needed to set up an animal production and processing farm and to sustain productivity is a problem to their livelihood activities. According to McKay (2012), financial inadequacies have led to slow growing animal industries or moribund ones or even destroyed animal production industries. An adequate proportion, 39 (43.3\%) of the respondent confirmed that inadequate access to veterinary services constitute a problem to their livelihood, about $5.6 \%$ of the respondents agreed that governments policies is one the problems militating against their livestock production, 3.3\% of the respondents are faced with the problem of poor organization of animal product market, while an equal percentage $(1.1 \%)$ of the respondents confirmed that their livelihood activities is constrained by both inadequate extension advisers and climatic factors (dessert encroachment). Adesehinwa et al (2014) posited that there are a number of constraints confronting the livestock industry and impedes its growth and development most especially in the tropics. They listed inadequate feed and nutrition, inadequate 
breeding programme, diseases and pest infestations, land tenure, institutional problems and conflicts as the most limiting factors. However, Bamaiyi (2013) identified high cost of animal feeds, animal diseases, access to veterinary services-vaccines and drugs, level of education of farmers, market and storage facilities among others as factors militating against livestock production in Nigeria.

\section{CONCLUSION}

The study revealed that majority $(51.1 \%)$ of the respondents had above 100 cattle, majority $(54.4 \%)$ of the respondents had less than 50 sheep, majority $(85.6 \%)$ of the nomadic pastoralists had less than 50 goats, the mean number of cattle, sheep and goat owned by the respondents were estimated at $168.60,57.86$ and 31.28 respectively. while the mean annual income of the respondents was estimated at $\$ 294,388.89$. Majority of the respondents earned more than 100,000 thousand annually from the sales of livestock with a greater percentage (36.7\%) within the range of $\$ 101,000$ - N200,000

All $(100 \%)$ of the respondents utilize the natural grassland, majority $(91.1 \%)$ of the respondents own the cattle themselves, most $(83.3 \%)$ of the sheep are owned by the respondents themselves and $(87.3 \%)$ of the respondents owned the goat kept themselves, most $(87.7 \%)$ kept Sokoto Gudali breed, majority $(71.1 \%)$ of the respondents kept the Uda breed of sheep, most (85.6\%) of the respondents kept the West African Dwarf goats. On the constraints, land tenure was the most pressing constrain to majority $(64.4 \%)$ of the nomadic pastoralists in the study area.

This survey of the livelihoods of nomadic pastoralists showed that the majority of pastoral households in the study area are living a sedentary lifestyle utilizing the natural grassland and are holding little (less than 100) livestock with no access to rangeland resources. Pastoralists in the study area are vulnerable to land tenure probably resulting from communal clashes. It can also be concluded from the study that socioeconomic factors of pastoralists especially, years of experience, marital status and household sizes affect their lifestyle choices.

\section{RECOMMENDATIONS}

Based on the findings, the study recommends that;

i). Rangeland should be made available by the Nasarawa State Government and accessible to nomadic pastoralists in the study area.

ii). Further research by relevant stakeholders should be conducted on the livelihood of nomadic pastoralists in a broader scope in terms of the relationship between the herders and farmers, reflecting the present suspicious relationship between the two.

iii). More advocacy and sensitization/mobilization by Nasarawa State Government and NGOs in livestock production for the actors on regular basis to abreast situations in order to nip any unforeseen likely occurrences of conflict.

iv). General inventorization of existing natural resources available and redefining the community utilization of such resources among and between all the communities existing in the area.

v). Community conflict management/resolution committees should be established by the Local Government Councils with full support and comprehensive guidelines from the State Government along gender levels, i.e elders-women and men; youths-women and men, younger ones.

\section{REFERENCES}

[1] Ademosun, A.A. (1974). Utilization of Poor quality Roughages in the derived savannah Zone. In: Loosli, J.K., Oyenuga, V.A. and Babatunde, G.M. eds. Animal Production in the Tropics. Proceedings of the international Symposium on Animal production in the tropics, held at the University of Ibadan, Nigeria 2629 March 1973. pp 152-166.

[2] Adesehinwa, A. O. K.; Okunola, J. O. and Adewumi, M. K. (2004). Socio-economic characteristics of ruminant livestock farmers and their production constraints in some parts of South-western Nigerian. Livestock Research for Rural Development, 16 (8).

[3] Aregheore, E. M. (2001). The effect of supplementation of crop residues based diets on the performance of steers grazed on natural pasture during the dry season. African Journal of Range and Forage Science, 18: 25-29.

[4] Ayanda, I. F. (2013). Assessment of effect of climate change on the livelihood of pastoralists in Kwara State, Nigeria. Journal of Development and Agricultural Economics, 5 (10): 403-410

[5] Bamaiyi, P. H. (2012). Factors Militating against the control of Helminthosis in Livestock in developing countries. Veterinary World. Vol 5 (1): 42-47.

[6] Bamikole, M. A.; Ikhatua, U.J.; Arigbede, O.M.; Babayemi, O.J. and Etela, I. (2004). An evalauation of the acceptability as forage of some nutritive and antinutritive components and of the dry matter degradation profiles of five species of Ficus. Tropical Animal Health and Production,36: 157-167.

[7] Bhasin, V. (2011). Pastoralists of Himalayas. Journal of Human Ecology. 33(3):147 - 177

[8] Bourn, D., Wint, W., Blench, R., and Woolley, E.(2007). Identification and characterisation of West African shorthorn cattle. Nigerian Livestock Resource Survey, FAO cooperate document repository. Pp $1-12$.

[9] Carney, D. (1999). Sustainable Rural Livelihoods. What difference can we make? DFID, London.

[10] Chambers, R. (1989): Sustainable rural livelihoods: A key to strategy for people, environment and development, In Conroy, C. and Litvinoff, M. (eds): The greening of aid London, Earthscan

[11] Carter, M. R. and Barrett, C. B. (2006). The Economics of Poverty Traps and Persistent Poverty: Journal of Development Studies. 42(2): 178 - 199

[12] Fabusoro, E. (2006). 'Property Rights, Access to Natural Resources and Livelihood Security among Settled Fulani Agro-Pastoralists in Southwestern Nigeria', Research Report for International Foundation For Science, Sweden/United Nations University Institute of Advanced Studies, Yokohama Japan, Research Grant No. P/3735-1, under the Agriculture For Peace in Africa Split Fellowship Programme

[13] Fabusoro, E.; Lawal-Adebowale, O. A. and Akinloye, A. K. (2007). A study of rural livestock farmers' patronage of veterinary services for health care of small farm 
animals in Ogun State. Nigerian Journal of Animal Production.34 (1): 132 - 138.

[14] Food and Agriculture Organization- FAO (2001). Pastoralism in the new millennium. Animal production and health, Paper150. Food and Agriculture Organisation, Rome.

[15] Food and Agriculture Organization- FAO and ILO. (2009). The Livelihood Assessment Tool-kit: Analyzing and responding to the impact of disasters on the livelihoods of people. International Labour Organization (ILO), Geneva. 208pp.

[16] International Fund for Agricultural Development (IFAD) (2012).Livestock and pastoralists. Livestock Thematic Papers: Tools for project design. 1-8pp

[17] Ismaila, U.; Gana, A.S.; Tswanya, N. M. and Dogara, D. (2010). Cereals Production in Nigeria: Problems, constraints, and opportunities for betterment. Africa. $J$. Agric. Res. 5(12):1341-1350.

[18] Lawal-Adebowale, O. A. (2012). Factors Influencing Small Ruminant Production in Selected Urban Communities of Abeokuta, Ogun State. Nigerian Journal of Animal Production, 39 (1): 218 - 228.

[19] Leeuwis, C. and Pyburn, R. (2002). Wheelbarrows full of frogs. Social learning in rural resource management.Cees and Rhiannon Pyburn (eds,). Van Gorcum.

[20] .Manu, I. N.; Bime, M. J.; Fon, D.E. and Nji, A. (2014). Effects of farmer-grazer conflicts on rural development: a socio-economic analysis. Scholarly J. Agric. Sci. 4(3): $113-120$

[21] McKay, A. (2012). Growth and Poverty Reduction in Africa in the Last Two Decades: Evidence from an AERC Growth-Poverty Project and Beyond. Journal of African Economies. Vol 22 (suppl 1): 149-176.
[22] Meteorological Department (2008). Nigerian Metrological Agency (NIMET): Nasarawa State Geography.

[23] National Population Commission (NPC), (2006). Population and Housing Census of the Federal Republic of Nigeria: National and State Population and Housing Tables, Federal Republic of Nigeria - Abuja.

[24] Nori, M. (2006): The relevance of camel of milk marketing to Somali pastoral livelihoods.

[25] Nori, M.; Switzer, J. and Crawford, A. (2005). Herding on the Brink: Towards a Global Survey of Pastoral Communities and Conflict - An Occasional Paper from the IUCN Commission on Environmental, Economic and Social Policy; Gland (Ch)

[26] Nyagba, J. L. (1995). The geography of Benue State. In: Denga D.I. ed. Benue State: The Land of Great Potentials. Calabar: Rapid Educational Publishers pp.8497.

[27] Nyangile, W. J. (2013). Comparative study of livelihood strategies and food Security of recent migrants and nonmigrants in Kilombero Valley. Unpublished Thesis Submitted in Partial Fulfillment of the Requirements for the Degree of Master of Arts in Rural Development of Sokoine University of Agriculture. Morogoro, Tanzania. $12 \mathrm{p}$.

[28] Omotayo, A. ; Chikwendu, D. O. and Adebayo, K. (2001). Two decades of World Bank assisted extension services in Nigeria: lessons and challenges for the future. The Journal of Agricultural education and extension. Vol 7 (3): 143-152.

[29] Turner, M. D. (2009). Capital on the Move: The changing relation between livestock and labour in Mali, West Africa. Geoforum. 40(5): 746 - 755

[30] Wikipedia (2016). Wikipedia: The Free Encyclopedia, Nasarawa State. 